\title{
Male and female English students' perspectives in English speaking class activities
}

\author{
Adi F. Mahmud*1, Adamu M. Babikkoi² \\ ${ }^{1}$ Universitas Muhammadiyah Maluku Utara, Ternate, Indonesia \\ e-mail: *mahmud_adif@yahoo.com \\ ${ }^{2}$ Federal College of Education, Yola, Nigeria \\ e-mail: abalbashar5@yahoo.com
}

\begin{abstract}
This research aims to investigate male and female English students' perspectives in English speaking class activities. This research applied qualitative approach with the descriptive qualitative design. Unstructured interview technique used to collect the data of this study. The researcher interviewed ten participants who consist of five male and five female at English students of Universitas Muhammadiyah Maluku Utara. The participants are from the third semester to the fifth semester who have joined English speaking class activities. In analyzing data, the researcher followed three steps consists of reading/memoing, describing, and classifying. In the Reading/memoing step, the researcher transcribed all results of the interview from the recorder and read transcription to catch the initial sense of data. The describing step lead the researcher to develop the thorough and comprehensive description of participants, setting, and the phenomenon of the research to cover the rich complexity of the research. In classifying stage, the research made the research data and brooked it down into a smaller unit, put the appropriate unit together in more general and analytic form. Results showed that there are four main perspectives revealed by students (1) language used by a lecturer in English speaking activities, (2) learning approaches, (3) learning strategies, and (4) learning the place. Then, male and female students' stated similar perspectives, (2) Male and female students' perspectives do not in line with lecturers perspectives in English speaking class activities.
\end{abstract}

\section{Keywords:}

Male and Female students, speaking activities perspectives, teaching approach

\section{INTRODUCTION}

As English language learners who had studied English intensively, they should be able to communicate orally instead in their daily life or in an academic context. Speaking is one of the critical skill of learning a language. Speaking is a way of communicating an idea or though orally to other people. To make students enable to communicate well in target language learning, the teachers should apply the target language communication in real practice. Brown, Yule, and McKelvie (1986) stated that speaking is how to communicate information based on the complexity of the information, but the speaker sometimes gets difficulties to explain or clarify what they want. Chun and Frodesen (2014), Larsen-Freeman and Long (2014), Slabakova (2016), Hughes (2013) revealed that speaking is one of the first ways of children to acquire a language, it is a 
part of involvement form most people in daily activities of language, and it is a primary language motor change. It also provides our original records to understand bilingualism and language contact.

Accordance with the context above, it can be claimed that to be a good English speaker is not easy such as EFL students. Good English speakers are demanded not only master the verbal skill, but they also dominate the particular of language speaking competences who stated by Thornbury (2011) and Nakamura (2015) that consist of speech production, conceptualization and formulation, articulation, automaticity, and self-monitoring and repair. Others components are speaking more focus on how to produce words or utterance, pronunciation, fluency, and accuracy than grammar. On the other hand, speaking skill not only producing word by word or utterance by utterance but, the speakers also should master the speaking competences.

Besides problem which presented before, there are some cases appear in learning English speaking namely; teachers' teaching methods, classroom facilities, and different gender of students. Teacher's methods such as giving a less great deal of opportunities to practice the target language. The class focus on teacher-centered rather than student-centered approach. Long and Porter (1985) mention the lack of opportunity to practice the target language in teaching in the classroom, the learner gained low achievement. Many English teachers also using traditional method in teaching English speaking (Mahmud \& Rahman, 2015). Therefore, teachers should design teaching activities in the classroom and give the best facilitation of speaking exercises.

Moreover, the use of speaking English in the class activities must be addressed to the students and using only the target language (Westbrook, 2011:3). The next problems are the different gender of students. This is one kind of issues that give a contribution to learning achievement. Many educational research findings in the last decade proved that gender differences give influence of students' academic achievement, interests and need (Collins, Collins, McLeod, \& Kenway, 2000). Regarding the communication, males and females show different styles. Lakoff (1973) studied that female's communication prefer to use high intonation, politeness, most emphatic, and question. From these cases, this research tried to investigate different kinds of gender. In cases are male and female students' perspectives on English speaking class activities and find out any differences of male and female students' perspectives. The following questions were of particular interest.

a) What are male and female English students' perspectives in English speaking class activities?

b) Are any differences between male and female English students' perspectives?

\section{Method}

This research applied qualitative approach by using descriptive qualitative design. This section consists of procedure and data analysis of the study. The details of the method used in this study are described in the following subsections. 


\subsection{Procedure}

To collect the data of this research, the researcher used unstructured interview technique. The researcher interviewed ten participants who consist of five male and five female at English students of Universitas Muhammadiyah Maluku Utara (UMMU), Indonesia. The participants are from the third semester to the fifth semester who have been joined English speaking class activities. The interview took place at language laboratory at UMMU for two days. The first day conducted $19^{\text {th }}$ of August 2017 with five male students, and the second day in $20^{\text {th }}$ of August 2017 with five female students.

\subsection{Data analysis}

In analyzing research data from the interview, the researcher followed three steps adopted from (Gay, Mills, \& Airasian, 2009). The steps namely (1) reading/memoing, (2) describing, and (3) classifying. Reading/memoing; the researcher transcribed all results of the interview from the recorder and read transcription to catch the install sense of data, describing; it develops the thorough and comprehensive description of participants, setting, and the phenomenon of the research to cover the rich complexity of the research. Descriptions included data which collected through interview, and classifying; research data brook down into smaller unit, put the appropriate unit together in more general and analytic form. On the word, data coded, categorized, grouped into themes, then interpreted and presented qualitatively.

\section{RESUltS}

The results covered all male and female students perspectives in English speaking class activities. The perspectives address how English speaking class activities take place in the classroom. The students' perspectives focus on several components namely; (1) language used by a lecturer in English speaking activities, (2) learning approaches, (3) teaching strategies, and (4) the place of English speaking activities take place.

Data findings from interviews showed that most male and female students'perspectives are similar. The perspectives such as the language used by a lecturer in teaching English speaking, learning approaches, teaching strategies, and the place of English speaking activities take place. All students have the same perspectives. Ten students expected that lecturer mix two languages (Indonesia and English) alternately in English speaking activities. Students seemed to express that lecturer should implement the students-center approach rather than use teacher-center approach. Students experienced that they wish the teaching strategies change. The lecturer should provide a free chance for students to ask questions and give an opinion. Students also experienced that teacher should speak fully in English and forbid students to speak Bahasa in English speaking class activities. Also, students seemed to expect that teacher should give punishment to students who speak Bahasa in English speaking class and give more chance and motivation to students who are not active in English speaking class. Ten students stated learning free class is better than indoor. They also urged the students should choose the place of English speaking class activities. 
Data interview below indicated students' perspectives in English speaking class activities. Interviewed results of the language used by a lecturer in English speaking class activities.

I strongly agree because most of the students are from the remote area so that we have less English ability so that some of them hard to understand speaking English entirely. (five male students' responses)

The lecturer must combine two languages when the lecturer is on speaking class activities because of some of the students are less of vocabulary so that they feel difficult to understand the materials. If lecturer speaks in full of English, some of the students will be hard to understand. (five females students responses)

Interviewed results of using learning approaches (student-center approach better than teacher-center approach) in English speaking class activities

I strongly disagree if the lecturer is more active rather than students in the class, but the lecturer must give more chance to the students to ask questions, give suggestion and participation. (three male students responses).

I disagree, It must be balanced or students more active in speaking class activities so that the students can improve their speaking (two male students responses).

I strongly disagree, the lecturer gives a guideline, but the students must be active in learning. In new curriculum right now allow to students more active rather lecturers, the lecturer is only a facilitator. In learning, there are stimulus and response so that students can train their mentality in speaking in front of the class. It must be balanced so that the students also participate in improving themselves. (five female students responses)

Interviewed results of learning strategies in English speaking class activities

I agree because this is speaking class, so students are demanded to speak English in the class to train themselves in using English (one male student's response).

I strongly agree if the students are given much time to ask questions and suggestion but using English entirely because it will create a habit for students on learning English speaking. (four male students responses).

The lecturer must give free time to students for asking questions and speaking entirely English, because this speaking class but the lecturer does not correct their mistakes on the process of speaking, let them finish at all. This is speaking class so the students should be given time to speaking English entirely. Because it can train the student to be a habit on English speaking (five female students responses). 
We disagree lecturer give punishment because every student has different English ability. So that, the lecturer does not give punishment but give them a chance to improve themselves step by step. If the lecturer gives punishment, they will down. (four male students responses).

I agree lecturer gives punishment to students who speak Indonesian on English speaking class because if the lecturer punishes them, the students will try to study hard, but the punishment such give an assignment. (one male student response).

I agree with giving punishment, but the punishment is such as assignment that related to improving they are speaking such memorize vocabulary for next meeting. I agree lecturer gives punishment so that there is a positive effect on students to study hard in improving their speaking. (five female students responses).

We agree if the lecturer gives more chance and motivations to students who are not active and less participation because they have the same right and they will feel lecturer give attention to them. So, they will be active and participate well. (five male and female students responses)

Interviewed results of English speaking activities take place

In my mind, learn to speak is not only indoor class, but it can be outdoor such in the fortress, beach so that the students can descript the history place and tourism place. I heartily agree, because an outdoor class can give the new situation to students and we can see something which does not see inside of the class. Moreover, the outdoor class makes students fresh, close to the environment; students can descript environment around them that we do not see in the classroom. The outdoor class also lose students' rigidity in speaking practice. (five male and female students responses).

\section{DISCUSSION}

Based on above research findings, it indicated that there are four perspectives come from male and female students. Those perspectives are the language used by a lecturer in teaching English speaking, teaching approaches, teaching strategies, and learning the place. Most of the students' perspectives contradicted with a lecturer who is teaching speaking subject at English Department of Universitas Muhammadiyah Maluku Utara (UMMU). Such as language used by a lecturer in English speaking Activities. According to students, the lecturer should speak two languages (Indonesia and English) alternately. The students stated these because some reasons; most of English students at UMMU are from the remote area so that they have the low English ability, most of the students lack vocabularies, therefore, using English fully in English speaking activities make them difficult to understand. This perspective does not in line with (Westbrook, 2011). Westbrook stated that

DOI: 10.33750/ijhi.v1i1.2 
using only the target language in the classroom, it has benefits for students who learn the foreign or second language.

The students also viewed that students-center approach is better than using teacher-center approach. Learning strategies applied by a lecturer in English speaking activities should include some points such (1) lecturer should give much chance to students to ask questions, delivery opinion, (2) speak fully English, (3) and give punishment to students who speak Bahasa. Learning strategies in point one are supported by Long and Porter (1985) study. They argued that students lack the chance to practice the target language in learning will lead low achievement. On the words, students' perspectives related to teaching strategies can be used by a lecturer to teach English speaking.

Besides language use, learning approaches, and learning strategies above, the students also stated difference perspectives related to the place of English speaking activities take place. All the students presented that outdoor class is better than indoor. According to students, the free class gives some benefits such as, find a new situation, students are first, students, can describe the environment around them, and learning in outdoor can lose students' rigidity in speaking practice.

\section{CONCLUSION}

Based on above findings and discussion, it can be concluded into several vital points in this research Male, and female students' stated four main perspectives in English speaking class activities, namely language use, learning approaches, learning strategies, and the place of activities. Male and female students give similar perspectives on English speaking class activities. Male and female students' perspectives do not in line with lecturers perspectives in English speaking class activities.

\section{REFERENCES}

Brown, G., Yule, G., \& McKelvie, N. (1986). Teaching the Spoken Language. RELC Journal, 17(1), 97-99. https://doi.org/10.1177/003368828601700108

Chun, D. M., \& Frodesen, J. (2014). Second language acquisition.

Collins, C., Collins, C. W., McLeod, J., \& Kenway, J. (2000). Factors influencing the educational performance of males and females in school and their initial destinations after leaving school. Dept. of Education, Training and Youth Affairs.

Gay, L. R., Mills, G. E., \& Airasian, P. W. (2009). Educational research: Competencies for analysis and applications, student value edition. Upper Saddle River, NJ: Merrill.

Hughes, R. (2013). Teaching and Researching: Speaking. Taylor \& Francis.

Lakoff, R. (1973). Language and Woman's Place. Language in Society, 2(1), 45-80.

Larsen-Freeman, D., \& Long, M. H. (2014). An introduction to second language acquisition research. Routledge.

Long, M. H., \& Porter, P. A. (1985). Group Work, Interlanguage Talk, and Second Language Acquisition. TESOL Quarterly, 19(2), 207.

Mahmud, A. F., \& Rahman, A. Q. (2015). The analysis of English lecturers'teaching models at English Education Department of Muhammadiyah University of North Maluku Ternate. ELT WORLDWIDE, 2(1), 125-135. 
Nakamura, E. (2015). Allocation of attention in EFL learners' oral performance across multiple task repetitions. Lancaster University.

Slabakova, R. (2016). Second language acquisition. Oxford University Press.

Thornbury, S. (2011). How to Teach Speaking. Longman.

Westbrook, F. (2011). Lessons from the Other Side of the Teacher's Desk: Discovering Insights to Help Language Learners. English Teaching Forum, 49(1), 2-7. 